\title{
名水を訪ねて（134） 山梨県・都留の名水
}

\author{
内山美恵子*
}

\section{Visit to valuable Water Springs (134) Valuable springs in Tsuru, Yamanashi}

\author{
Mieko UCHIYAMA*
}

\section{1. はじめに}

都留市は山梨県の東部 N35³3’ 5.6”, E1385 ’ $19.9 ”$ に位置し, 面積 $161.63 \mathrm{~km}^{2}$, 人口 29,511 人 (2021年 4 月 1 日現在 : 都留市, 2021), 城下町の 面影を残す小都市である。本市は北から時計回り に, 山梨県大月市, 上野原市, 道志村, 山中湖 村, 忍野村, 富士吉田市, 西桂町と接する。都留 市は古来より関東圈と富士北麓を結ぶ交通の要衝 であり, 旧石器遺跡が 2 地点, 縄文遺跡が57地 点報告されており, 太古より人々の営みが続い ていることがわかる(都留市史編集委員会編 $\mathrm{a}$, 1996 ; 都留市文化財審議会編, 1976)。江戸時代 になると, 将軍家御用のお茶を京都宇治から江戸 まで運ぶお茶壷道中の中継地となり, 江戸幕府の 公式史書である「御実紀 (徳川実紀)」には, 冷 涼な気候によりお茶の一部を勝山城にて一夏預か り秋に届けた時期もあった，との記録もある（都 留市立図書館 HP)。産業は古くは養虫が行われ, 甲斐絹に代表される繊維工業が盛んであったが, 現在は機械金属工業を中心とする製造業が主要な 産業となり, 観光産業や湧水を利用した水掛菜栽 培などの農業も盛んである（写真 1$)$ 。また, JR
東海のリニア中央新幹線実験線の拠点基地がある ことでも知られている。

市民が使用する水道水はすべて地下水でまかな われている。都留市では「都留市地下水保全条例」 を制定し，2018年10月 1 日からその運用を始め た。さらに地下水モニタリングのために市内 8 カ 所に地下水位観測井を設置して，2019年 4 月より 自記水位計による連続地下水位変動測定を実施し ている。2020年 2 月に水位計のメンテナンスが実 施され，筆者は市の協力を得て地下水観測井の地 下水を採水した。本論では, それら地下水試料と 周辺の湧水試料の水質について紹介する。なお, 正確には湧水は地下水が湧出したものであるが, 本論では湧出したものを湧水, 湧出する前の帯水 層中にあるものを地下水と表記する。

\section{2. 都留の自然環境}

都留市は市内総面積の $84 \%$ が森林（都留市, 2013）であり，人々は主要な河川沿いに集落を 作って暮らしている。標高は大月市と接する田 野倉地区が約 $400 \mathrm{~m}$, 西桂町と接する桂町地区が 約600 m であり，その差が大きい。市役所があ

\footnotetext{
* 都留文科大学教養学部学校教育学科（†402-8555 山梨県都留市田原3-8-1)
}

Department of Teacher Education, Faculty of Liberal Arts, Tsuru University 
る500 m 地点での気温は，2018～2020年の平均值 で，最低月平均值が 1 月の $2.5^{\circ} \mathrm{C}$, 最高月平均值 が 8 月の $26.1^{\circ} \mathrm{C}$, 年間平均值が $13.9^{\circ} \mathrm{C}$ である。降 水量は年間 $1600 \mathrm{~mm}$ 程度, 梅雨から夏季に豊水 期，冬季に渇水期を迎える（都留市地域環境課， 2021)。図 1 に都留市地名図を示す。

都留市の南部は標高 $1681 \mathrm{~m}$ の御正体山を始め とする道志山塊が占め, 西部は標高 $1785 \mathrm{~m}$ の三 ツ峠山などの御坂山地が占める。これら山地を浸 食して，相模川（桂川）が市域の南西から北東方 向に流動する。この河川は山梨県では古来より桂 川の名称で親しまれているため, 本論では以降, 相模川を桂川と称する。富士北麓の山中湖周辺に 端を発し西流する桂川は, 忍野村を過ぎ富士吉田 市に入ったあたりで北方向に向きを変え，道志山 塊と御坂山地が対峙する桂川渓谷に入り北東方向 へ流動する。都留市を流れる河川は, 三ッ峠山を
水源とし, 桂川に平行して東流する柄杓流川, 市 域南部から北流する鹿留川，菅野川，朝日川，市 域北部を東流する大幡川などが桂川に合流する。

\section{3. 都留の地質}

地質学的に都留市は, 南部フォッサマグナに属 する。尾崎・杉山（2018）によると，南部フォッ サマグナは新生代新第三紀中新世中期（およそ 16Ma）から開始した，フィリピン海プレートの 北西進に伴う伊豆弧との多重衝突によって特徴付 けられ，新第三紀中新世後期（7Ma 以前）に衝 突した丹沢地塊と，第四紀更新世（2.6Ma）に衝 突した伊豆地塊が関東山地の南方に配列してい る。都留市には丹沢地塊の衝突に伴う新第三系中 新統の西八代層群 · 丹沢層群が分布し，水中火山 砕首岩類と石英閃緑岩類の貫入岩体からなる（天

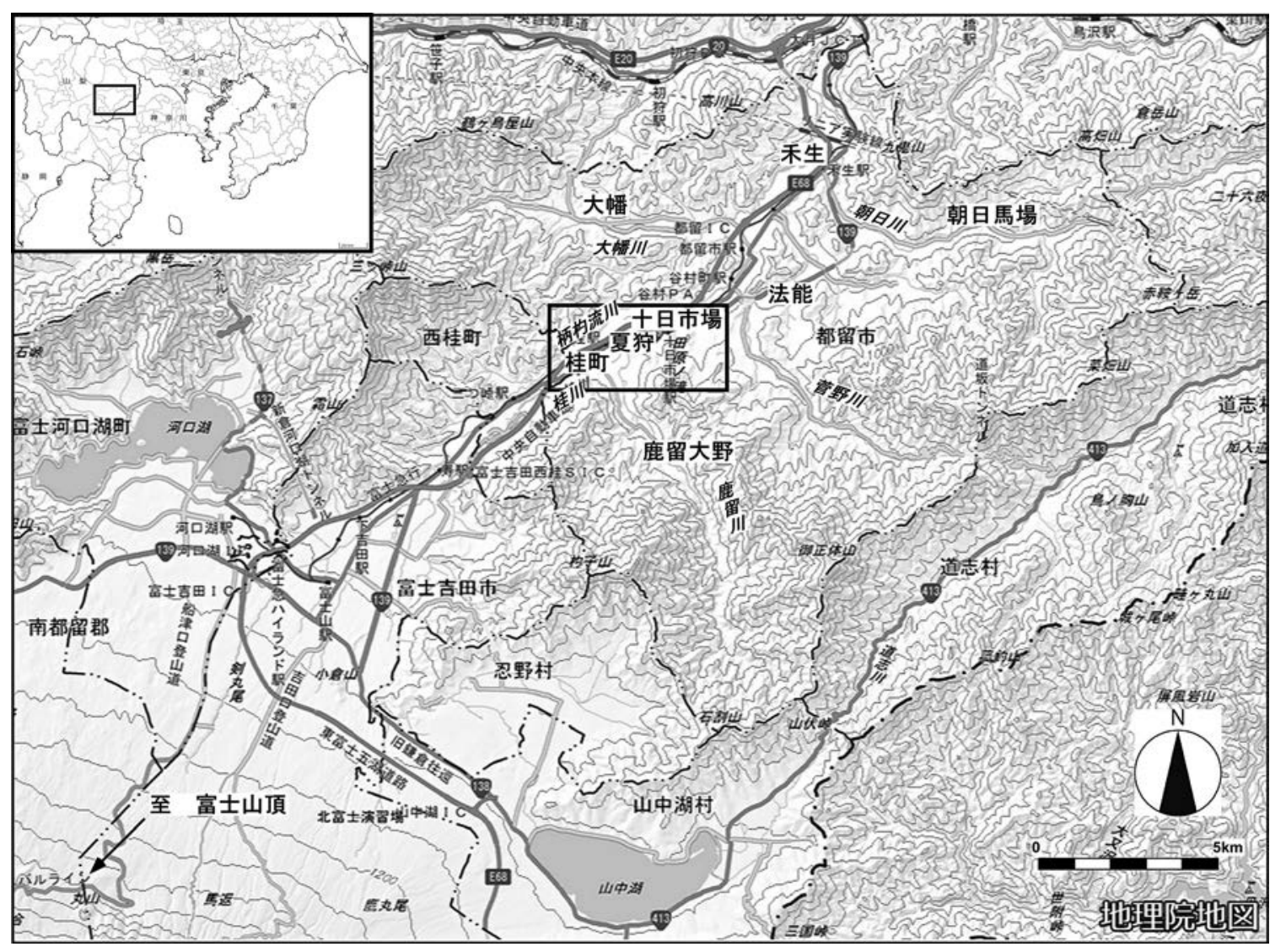

図 1 都留市地名図

図中の $\square$ は図 3 の範囲を表す。地形図は地理院地図を使用。 
野ほか, 2011)。図 2 に都留市の地質図(都留市 史編集委員会編 b，1996に加筆）を示す。

これら新第三系の中央部に桂川渓谷が形成さ れ，その渓谷内を富士山から供給された流下堆積 物や溶岩流が流下し, さらに周辺山地部も含めて テフラ群に被覆される。都留市に分布する第四系 は下位より, 古富士火山が崩壊する前に形成され ていた桂川（以降，本論では古桂川と称する）の 河川堆積物である砂砂層, 古富士火山の山体崩壊 によりもたらされた岩屑なだれ堆積物, その後数 回にわたって発生した土石流堆積物, テフラを挟 んで新富士火山活動初期に噴出した玄武岩溶岩 と, 桂川などの河川により形成された段丘砂層, 現河床堆積物である。岩屑なだれ堆積物と土石流 堆積物はまとめて古富士泥流 (町田, 2011) と命 名されている。都留市夏狩地区の太郎次郎の滝で 観察すると，柄构流川の水面あたりに岩屑なだれ 堆積物が分布するが, いくつものチャネルを充填
するように分布するため, 古富士泥流が流下する 以前の古桂川は川幅が広く網状河川であったと考 えられる(口絵写真 B )。古富士泥流堆積物はこ の古桂川の作った渓谷を約 $20 \mathrm{~m}$ の厚さで埋め尽 くし, 都留の市街地や田畑の土台を形成した。市 内東桂地区（桂町から十日市場にかけての地区） で掘削されたボーリングコアを観察すると, 古富 士泥流と上位の溶岩の間には赤褐色のスコリアが 約 $2 \mathrm{~m}$ 堆積している。新富士火山活動初期の富 士宮期には，割れ目火口より粘性の低い玄武岩溶 岩が大量に噴出するが, 都留市ではそのうちの 2 枚が確認できる。いずれも約 1 万年前頃（内山, 2020）に溶岩トンネルを形成して流動した長大溶 岩で, 下位より猿橋溶岩および桂溶岩（津屋, 1971）である。猿橋溶岩は桂川を流路として大月 市猿橋に至った。東桂地区では桂川周辺は猿橋溶 岩により埋積されたため, その後噴出した桂溶岩 は相対的に低地である猿橋溶岩の北側を柄杓流川

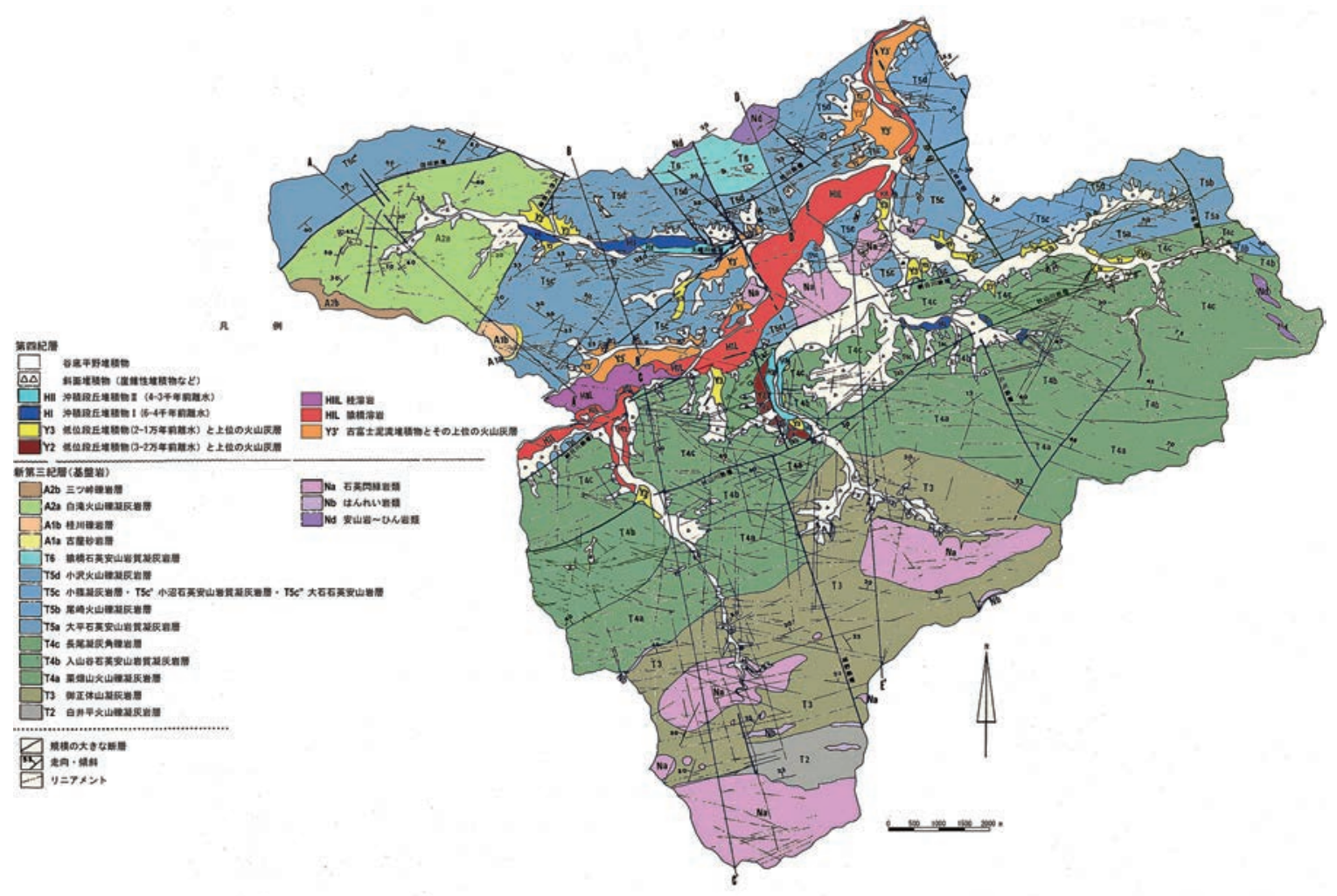

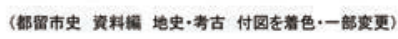


に沿って流動し, 東桂地区十日市場に到達した。

水文地質学的には基盤岩の新第三系は不透水層 となっているが，断層とそれに伴う破砕帯を地下 水が流動している。第四系では古富士泥流が難透 水層となり, その上位の猿橋溶岩 (写真 2 ) と桂 溶岩が不圧帯水層を, 下位の古桂川堆積物の砂礫 層が被圧带水層を形成している。富士北麓ではこ れら帯水層の透水係数について, 不圧帯水層で ある富士宮期の溶岩は $1.6 \times 10^{-6} \sim 6.5 \times 10^{-5} \mathrm{~m} / \mathrm{s}$, 難透水層の星山期古期泥流（古富士泥流）は $10^{-6} \mathrm{~m} / \mathrm{s}$ オーダー, 被圧带水層に対比される星 山期の火山砂礫層は $1.1 \times 10^{-4} \sim 2.0 \times 10^{-5} \mathrm{~m} / \mathrm{s}$ と 見積もられている (内山, 2020)。富士北麓の星 山期火山砂礫層は火山山麓扇状地を形成するよう

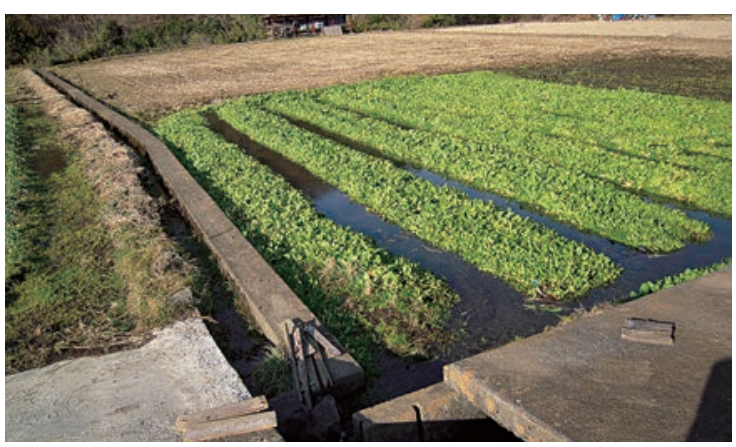

写真 1 水掛菜

冬の水田で湧水を引き入れて栽培する。かつ ては冬の貴重なビタミン源であった。

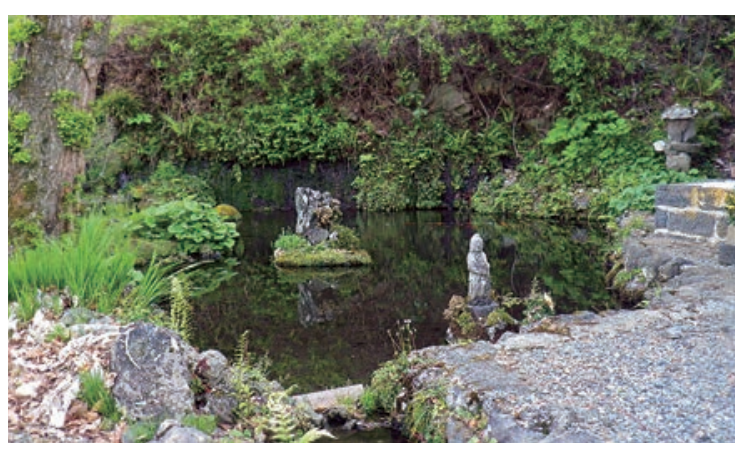

写真 3 永寿院湧水池

正面露頭の桂溶岩・古富士泥流境界部から湧 水している。
な砂礫層であると考えられるため, そのまま適応 はできないであろうが, 古富士泥流と溶岩の透水 係数はオーダー的には同等であろうと推定でき る。

\section{4. 都留市の名水}

都留市は水道水源のすべてを地下水に依存して いる。その中でも水量を誇るのが桂川渓谷内で湧 水する十日市場·夏狩湧水群 (口絵写真 A.B) で, 環境省の平成名水百選の一つに指定されている。 十日市場・夏狩湧水群はその名のとおり, 東桂地 区の夏狩から十日市場にかけての湧水地带で, 数 多くの湧水を観察することができる（図 3 )。湧

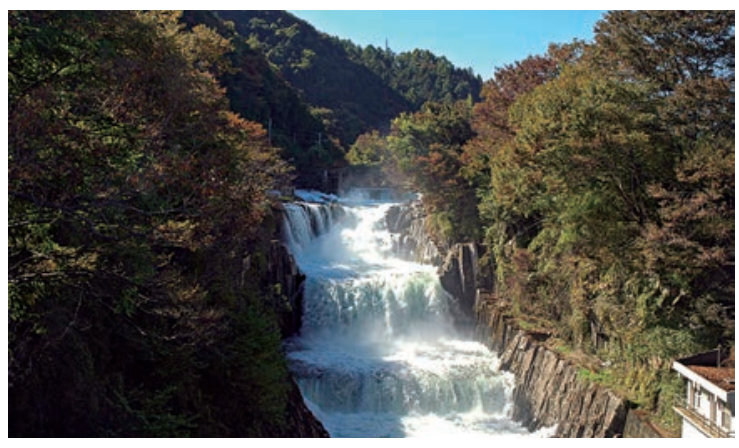

写真 2 田原の滝と猿橋溶岩

猿橋溶岩より湧水した水を右手手前のコンク リート妌に受けて配水している。溢れた水は 川へ戻している。河川水に接する部分は, 景 観に配慮して溶岩の柱状節理に似た護岸壁を 施している。

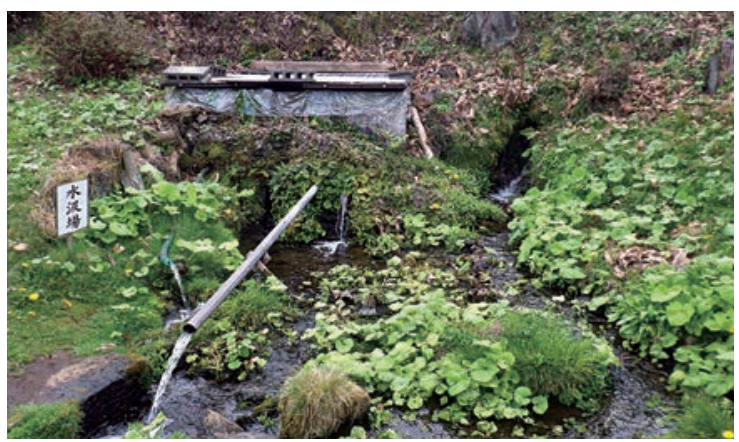

写真 4 永寿院水汲み場

桂溶岩の末端より大量に湧水している。 
水は桂溶岩の末端から湧出しており, 桂溶岩の側 方北側と先端部で見られる。湧出メカニズムは, 溶岩に浸透した富士山体の降水が流動経路の途中 での降水も付加しながら古富士泥流との境界部を ピストン流として流動し, 溶岩の末端から湧水し たものである（写真 $3 \sim 6$ )。その根拠は次節で 述べる。その水文地質構造は, ボーリング調査結 果より古富士泥流の上面が北に向かって傾斜する 傾向にあり, そのため湧水地点が北側の桂溶岩末 端に集中していることが推定される。

また，古富士泥流より下位の古桂川による河川 堆積物中にも豊富な地下水が肧胎されており, こ の地下水が都留市東部地区の水道水源となってい る。地下水は $30 \mathrm{~m}$ 以上被圧されており, 桂川の 氾濫原では放置された揚水管から自噴しているの



写真 5 長慶寺前湧水池

正面露頭の水面付近より湧水している。時期 には梅花藻が咲き乱れる。

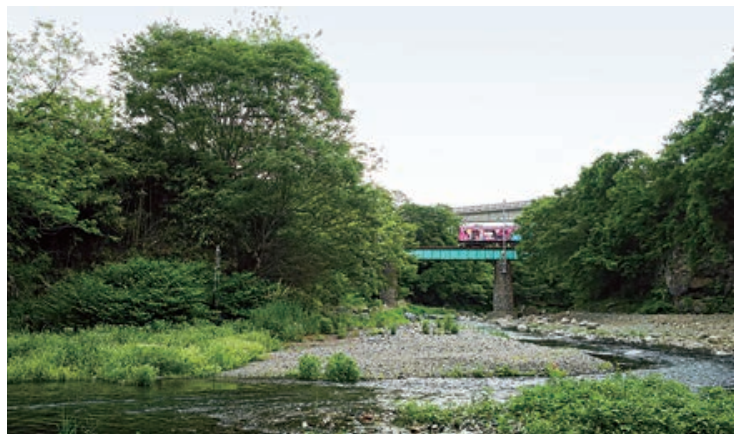

写真 7 禾生地区の被圧水

左の方に放棄された揚水管から自噴している のが確認できる。橋梁を渡っているのは富士 急電鉄, その奥はリニア中央新幹線の実験線。
が観察できる（写真 7$)$ 。

\section{5. 水質の特徵}

十日市場・夏狩湧水群のうち 7 地点, および市 内 8 地点の地下水の帯水層区分と採水時に測定し た水質, および主要イオン分析結果を表 1 に示 す。イオン分析 $\left(\mathrm{Na}^{+}, \mathrm{K}^{+}, \mathrm{Ca}^{2+}, \mathrm{Mg}^{2+}, \mathrm{Cl}^{-}\right.$, $\left.\mathrm{SO}_{4}{ }^{2-}, \mathrm{NO}_{3}{ }^{-}, \mathrm{PO}_{4}{ }^{3-}\right)$ はイオンクロマトグラフ 法により, $\mathrm{HCO}_{3}{ }^{-}$は硫酸滴定法により求めた。

湧水・地下水の主要イオン分析結果をへキサダ イアグラムにして，それぞれ図 3 および図 4 に示 す。地下水位観測地点は事情により地点の詳細を 示せないので, 地名図上に結果を示した。また, 帯水層ごとのトリリニアダイアグラムを作成し,

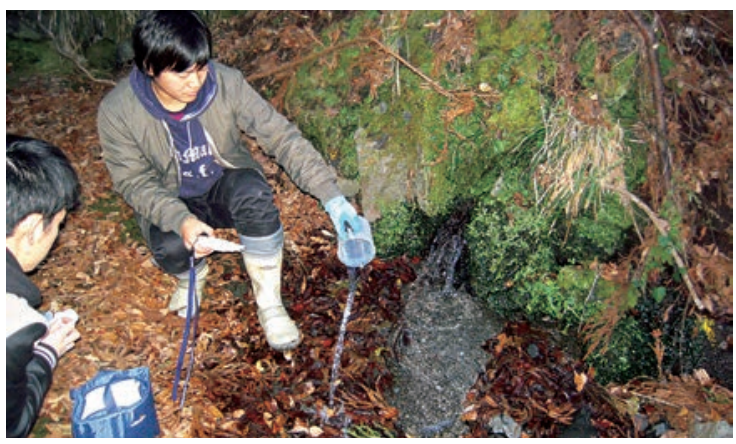

写真 6 渓山荘手前の湧水

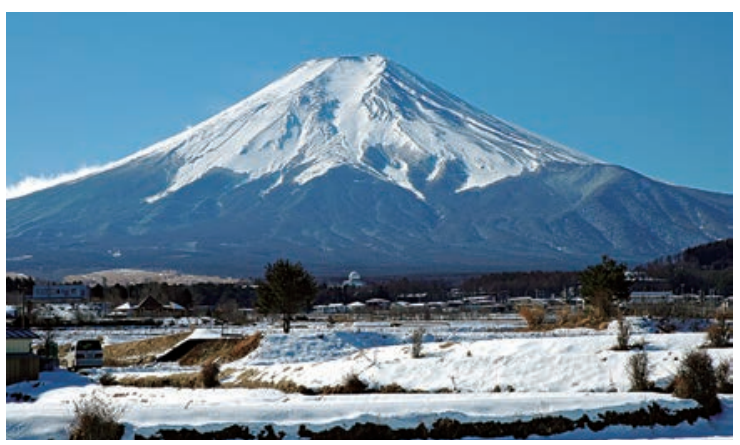

写真 8 富士吉田市より臨む富士山 十日市場・夏狩湧水群の涵養源 
表 1 分析結果

\begin{tabular}{|c|c|c|c|c|c|c|c|c|c|c|c|c|c|c|c|c|}
\hline $\begin{array}{l}\text { 8 } 8 \text { 料 } \\
\text { 番号 }\end{array}$ & 地点名 & 試料の種䅡 & 带水層 & 搮水日 & $\begin{array}{l}\text { 水温 } \\
\left({ }^{\circ} \mathrm{C}\right)\end{array}$ & $\mathrm{pH}$ & $\begin{array}{c}\mathrm{EC} \\
(\mathrm{mS} / \mathrm{m})\end{array}$ & $\underset{(\mathrm{mg} / \mathrm{L})}{\mathrm{Cl}^{-}}$ & $\begin{array}{c}\mathrm{NO}_{3}^{-} \\
(\mathrm{mg} / \mathrm{L})\end{array}$ & $\begin{array}{l}\mathrm{PO}_{4}{ }^{3-} \\
(\mathrm{mg} / \mathrm{L})\end{array}$ & $\begin{array}{l}\mathrm{SO}_{4}{ }^{2-} \\
(\mathrm{mg} / \mathrm{L})\end{array}$ & $\begin{array}{l}\mathrm{HCO}_{3}^{-} \\
(\mathrm{mg} / \mathrm{L})\end{array}$ & $\underset{(\mathrm{mg} / \mathrm{L})}{\mathrm{Na}^{*}}$ & $\underset{(\mathrm{mg} / \mathrm{L})}{\mathrm{K}^{*}}$ & $\begin{array}{c}\mathrm{Mg}^{2+} \\
(\mathrm{mg} / \mathrm{L})\end{array}$ & $\begin{array}{c}\mathrm{Ca}^{2+} \\
(\mathrm{mg} / \mathrm{L})\end{array}$ \\
\hline 1 & 滘山荘手前 & 湧水 & 桂楁岩 & $2017 / 8 / 31$ & 16.0 & 7.4 & 20.7 & 7.89 & 5.63 & n. a & 15.52 & 71.39 & 9.48 & 1.74 & 6.62 & 16.15 \\
\hline 2 & 長厦寺西 & 湧水 & 桂溶岩 & $2017 / 8 / 31$ & 14.7 & 7.3 & 19.4 & 7. 24 & 5. 30 & n. a & 12.47 & 72.00 & 9.03 & 1.89 & 6.23 & 15.62 \\
\hline 3 & 長鹿寺東 & 湧水 & 桂溶岩 & $2017 / 8 / 31$ & 13.9 & 7.3 & 19.2 & 6. 29 & 4. 96 & 0.56 & 11.64 & 75,05 & 8.95 & 1.80 & 4.80 & 18. 44 \\
\hline 4 & 能太郎神社付近 & 湧水 & 桂楁岩 & $2017 / 8 / 31$ & 13.9 & 7.4 & 16.7 & 4. 31 & 4. 64 & 0.50 & 9.21 & 65.90 & 6.83 & 1. 38 & 4. 39 & 15.71 \\
\hline 5 & 文大小屋 & 湧水 & 桂溶岩 & $2017 / 8 / 31$ & 13.7 & 7.1 & 19.4 & 5. 83 & 5.20 & 0.58 & 11.91 & 76.27 & 8.65 & 1.65 & 4. 90 & 18.90 \\
\hline 6 & 永毒院 & 漂水 & 桂楁岩 & $2020 / 2 / 18$ & 13.0 & 7.6 & 12.7 & 2. 94 & 4. 18 & 0.22 & 7.20 & 54.31 & 5.32 & 1.41 & 4. 26 & 11. 60 \\
\hline 7 & 田原潼の下 & 湧水 & 猜標溶岩 & $2020 / 2 / 18$ & 12.0 & 7.7 & 11.4 & 2. 13 & 3. 72 & 0.24 & 6.02 & 51.87 & 4. 64 & 1. 25 & 3. 90 & 11. 28 \\
\hline 9 & 夏狩 & 地下水 (不圧) & 桂溶岩 & $2020 / 2 / 20$ & 12.8 & 7.7 & 17.5 & 6.33 & 6.36 & 0.42 & 13.08 & 69.56 & 8.90 & 1.92 & 6.32 & 14. 87 \\
\hline 10 & 十日市場 & 地下水 (不圧) & 桂楁䇹 & $2020 / 2 / 18$ & 13.0 & 7.6 & 14.4 & 4. 05 & 4. 47 & 0.24 & 8.31 & 56.75 & 5.91 & 1.59 & 4. 48 & 12. 48 \\
\hline 11 & 鹿留大野 & 地下水（不圧） & 扇状地性堆積物 & $2020 / 2 / 20$ & 12.8 & 9.2 & 12.8 & 1.53 & 0.10 & n. a & 2. 09 & 73.22 & 5.92 & 0.84 & 3. 83 & 13.59 \\
\hline 12 & 法能 & 地下水（不压） & 厥状地性堆積物 & $2020 / 2 / 20$ & 13.3 & 7.2 & 12.1 & 2. 40 & 2. 60 & n. a & 11.16 & 50.03 & 4. 65 & 1.15 & 3.71 & 12. 49 \\
\hline 13 & 禾生 & 地下水 (被圧) & 古桂川形棵層 & $2020 / 2 / 20$ & 13.4 & 7.5 & 18.4 & 2. 80 & 1.78 & n. a & 21.19 & 77.49 & 8.17 & 0.91 & 5.37 & 20.03 \\
\hline 14 & 朝日馬場 & 地下水（不压） & 棏状地性堆積物 & $2020 / 2 / 20$ & 9.0 & 7.5 & 10.4 & 1. 33 & n. a & n. a & 3.90 & 52.48 & 3.78 & 0.31 & 2. 70 & 11.88 \\
\hline 15 & 大幡 & 地下水 (不圧) & 厥状地性堆積物 & $2020 / 2 / 20$ & 13.4 & 7.5 & 14.5 & 2. 25 & 4. 28 & n. a & 13,93 & 60.41 & 4. 94 & 0.65 & 4. 83 & 15.57 \\
\hline
\end{tabular}

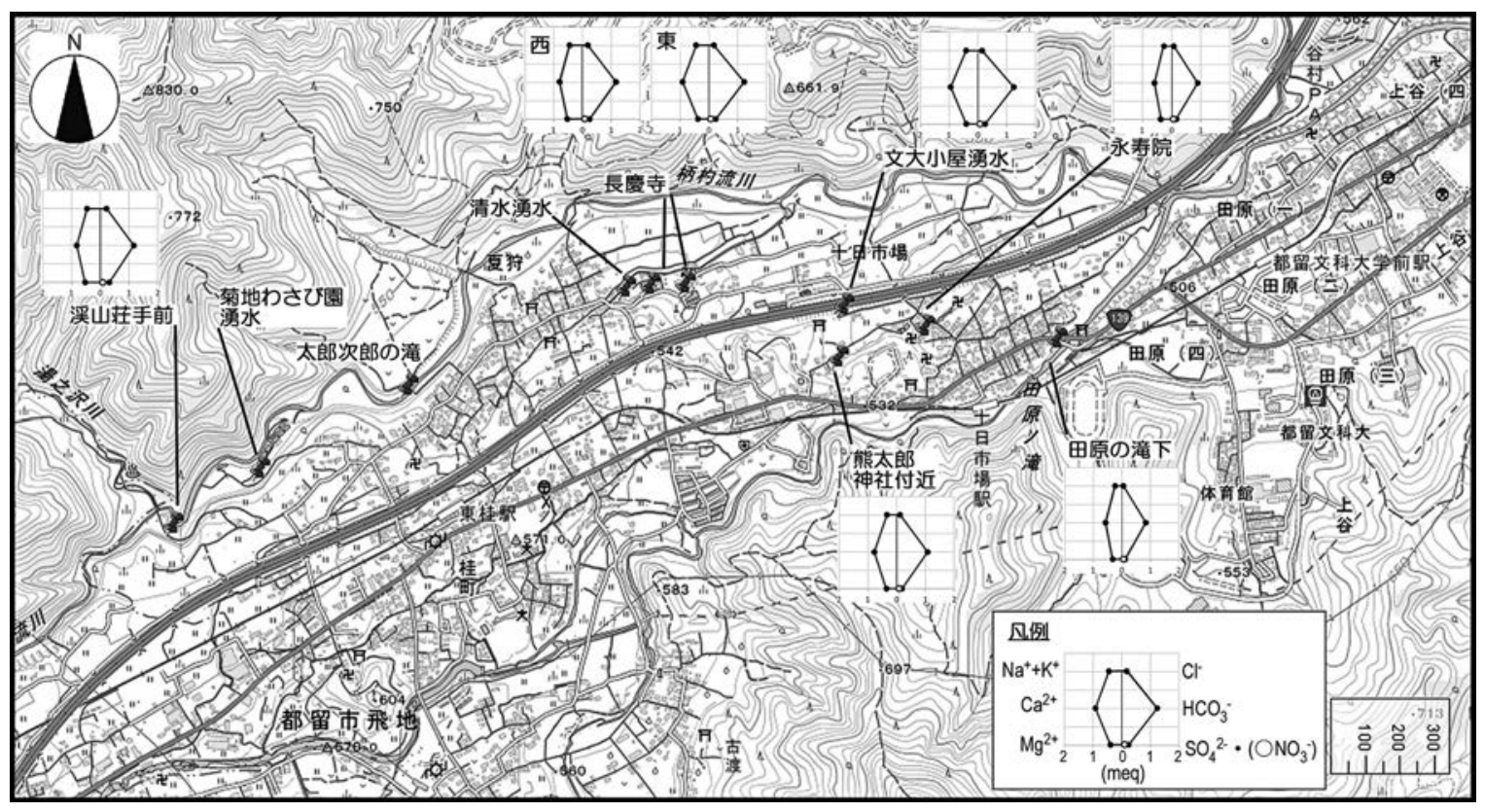

図 3 十日市場・夏狩湧水群の湧水地点とその水質

地形図は地理院地図を使用し，カシミール 3D を使用して加エした。

図 5 に示した。

これらより都留市の地下水は総じて炭酸ーアル カリ土類型の領域にプロットされ, 炭酸-カルシ ウム型であることがわかる。いずれも大きな違い は認められないが, 各イオン濃度は被圧水である 禾生地区の地下水が最も高い。この理由として, 被圧地下水は深い深度を流動しているため, そこ へ到達するまでに地下水と地層との接触時間が長 くなること, さらに禾生地域は朝日川との合流地 点にあたり, 朝日川の水源は海成層である基盤岩
からの地下水であることから，それらの影響も受 けていることが考えられる。また，十日市場・夏 狩湧水群の湧水については, 若干ではあるが桂溶 岩末端の永寿院と, 猿橋溶岩からの田原の滝下の イオン濃度が低い。これについては, 湧水量変動 や水の酸素・水素安定同位体比なども用いて, 別 の機会に報告する。

主要イオン分析とは別に, 十日市場・夏狩湧水 群の起源を探る目的で, 山梨県富士山科学研究所 にICP-Msによる微量元素の分析依頼を行った。 




図 4 都留市内地下水の主要イオン濃度 地形図は地理院地図を使用。

その結果，永寿院湧水に25 $28 \mu \mathrm{g} / \mathrm{L}$, 十日市場 および夏狩の地下水に30～ $37 \mu \mathrm{g} / \mathrm{L}$ の濃度でバナ ジウムが検出された。富士山麓の湧水や地下水 には, 湧水で約2 $4 \sim 47 \mu \mathrm{g} / \mathrm{L}$, 地下水で約 $51 \sim 71$ $\mu \mathrm{g} / \mathrm{L}$ のバナジウムを含むことが報告されている （小林·輿水，2005）。上記と同時に分析依頼し た，禾生地域に近い基盤岩からの湧水試料（本稿 では報告していない) のバナジウム濃度が 1 ～ 6 $\mu \mathrm{g} / \mathrm{L}$ であったので, 十日市場・夏狩湧水群の試 料はバナジウム濃度が有意に高く, 富士山体の地 下水が多く含まれると考えることができる（写真 8 )。

\section{6. おわりに}

都留市は東京方面から第一級の観光地である富 士山に向かう手前の市域である。富士山よりおよ そ30 km 離れ，深い渓谷中に位置するため富士山 が望める場所は限られているが，水をと扎して 富士山の豊かな恵みを感じることができる。その 水は地域の人々の暮らしを支え, 豊かな自然と動 植物を育み, それがこの地域の風土を形作ってき た。また，桂川から離れると，大地はかつての海 底火山で形成された岩盤からなり，その熱源は温 泉をも生み出している。様々な過程により形成さ れた地下水であるが, 都留市内の地下水はいずれ もイオンバランスの取れた飲み易く，産業にも利 


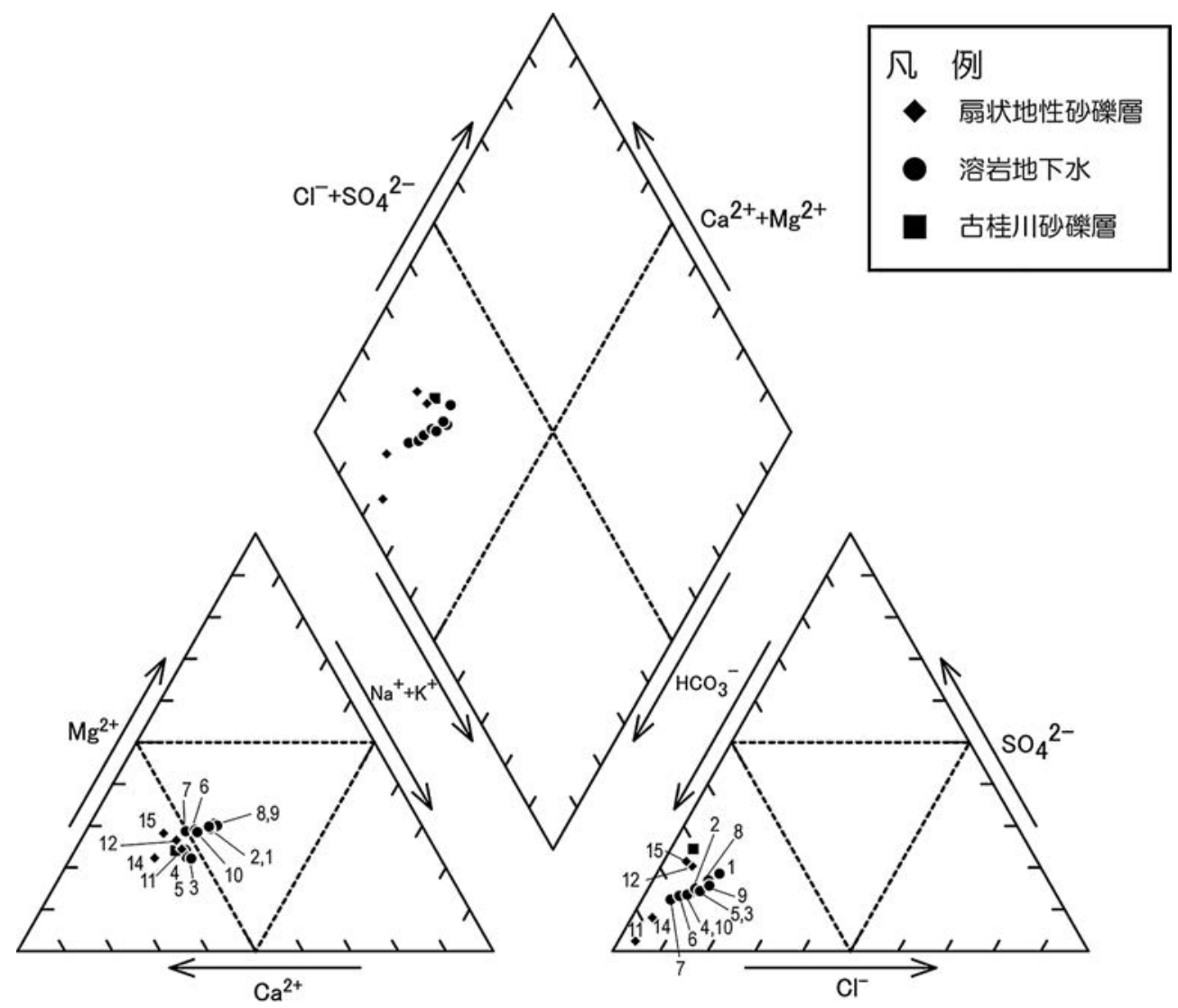

図 5 都留市名水の水質

ダイアグラム内の番号は表 1 中の資料番号を示す。 $\mathrm{NO}_{3}{ }^{-}$は検出したもののみ表示した。

用し易い水であるといえよう。しかしこの水環 境は正しく保全をしなければ維持できない。地域 の人々にとっては恵まれていると気がつかないほ ど，あって当たり前の湧水である。都留市だけで なく上下流地域の人々の関心を水環境に向け，流 域ぐるみで水環境の保全に取り組めるよう，今後 とも教育活動・普及活動に取り組む必要性を改め て強く感じている。

\section{謝辞}

地下水調査を行うにあたって, 永寿院ならびに 長慶寺のみなさま, 都留市役所地域環境課のみな さまにご協力をいただきました。水質分析を行う にあたって, 山梨県富士山科学研究所にお世話に なりました。本稿をまとめるにあたって, 同研究 所の内山 高博士と精読者の山梨大学の中村高志
博士には，有意義なご意見をいただきました。こ こに記して深謝申し上げます。

なお本調査にあたっては, 都留文科大学地域交 流研究センターの地域交流研究教育プロジェクト 研究費, 都留文科大学学術研究費を使用した。

\section{引用文献}

天野一男・松原典孝 - 田切美智雄（2011）：富士山の基 盤: 丹沢山地の地質 - 衝突付加した古海洋性島弧一. 富士火山, 日本火山学会, 59-68.

内山 高 (2020)：富士火山北麓扔よび富士五湖の水文 地質構造と水文学的特徵. 地学雑誌, 129, 697-724. 尾崎正紀・杉山雄一（2018）：身延地域の地質. 地域 地質研究報告 5 万分の 1 地質図副解説書, 東京 (8) vol.69, 産業技術総合研究所地質調查総合センター, 170p. 
小林 弘・舆水達司 (2005) : 地下水・湧水中のリンお よびバナジウム濃度関係を元に推定された河川水に おける人為的影響によるリン濃度. 地下水学会誌, 47, 97-115.

津屋弘達（1971）: 富士山の地形地質. 国立講演協会編, 富士山 - 富士山総合学術調査報告書, 富士急行, 151209.

都留市文化財審議会編 (1976): 都留市の先史遺跡 (上). 都留市教育委員会, 138p.

都留市史編集委員会編 a（1996）：都留市史 通史編. 都留市, 1073p.

都留市史編集委員会編 b (1996): 都留市史 資料兼 地 史·考古 (付図). 都留市, $537 \mathrm{p}$.
都留市 (2013) : 都留市森林整備計画. 80p.

都留市 (2021)：広報「つる」. No.728, 30p.

町田 洋 (2011)：富士山と周辺の火山. 日本の地形 5 中部, 東京大学出版会, 45-57.

都留市地域環境課（2021）：地下水位観測の報告 令 和 2 年版. 都留市, 内山美恵子監修, 13p. https:// www.city.tsuru.yamanashi.jp/material/files/group/7/ tikasui_2020.pdf. (2021.5.5閲覧).

茶壶道中（2002）：都留の歴史 近世. 都留市立図書館,

https://www.lib.city.tsuru.yamanashi.jp/contents/ history/ another/kinsei/tyatubo.htm. (2021.5.5閲 覧).

(受付：2021年 6 月 3 日, 受理：2021年 6 月14日) 


\section{山梨県・都留の名水}

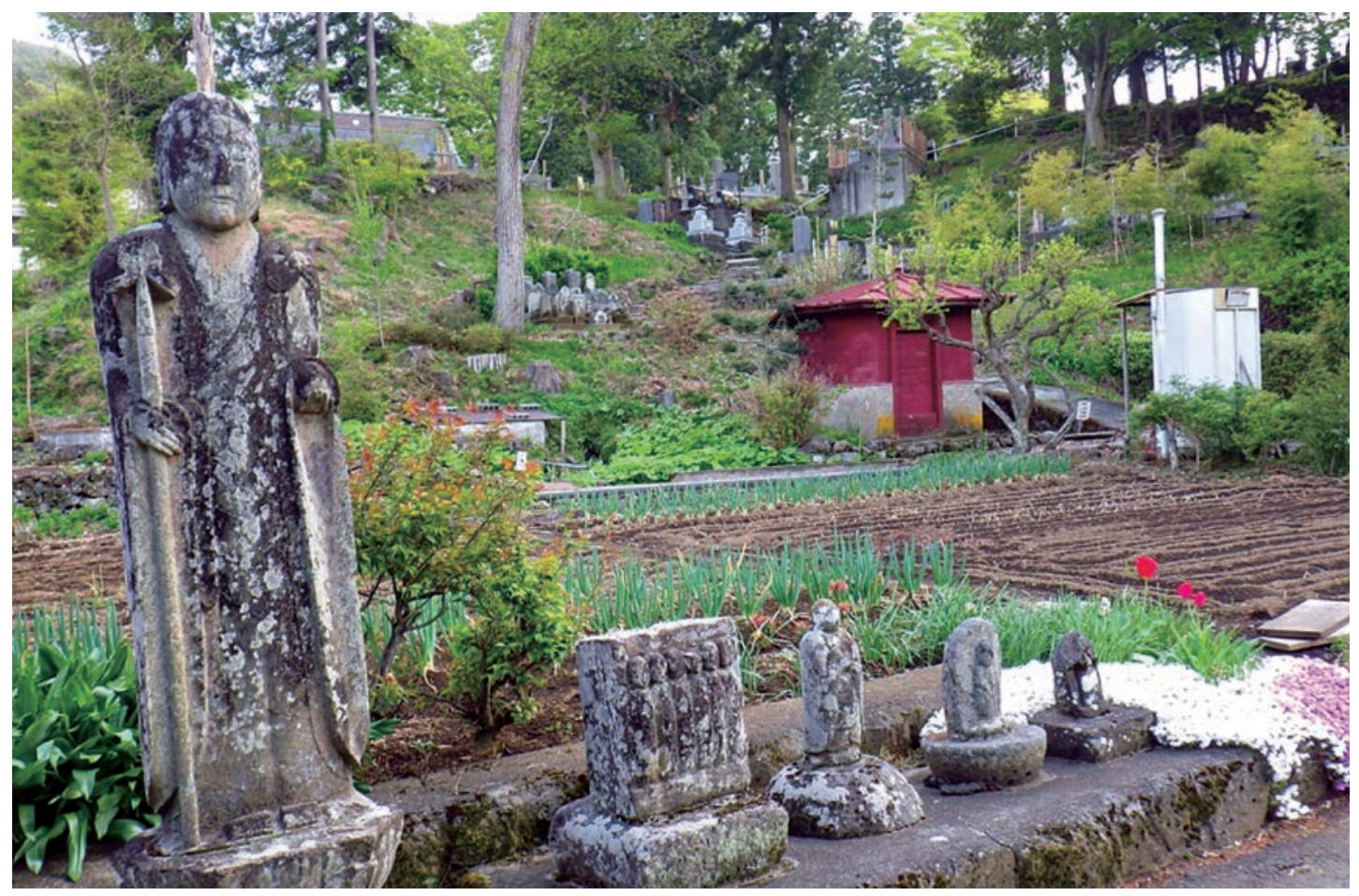

A 十日市場湧水群（永寿院入り口）

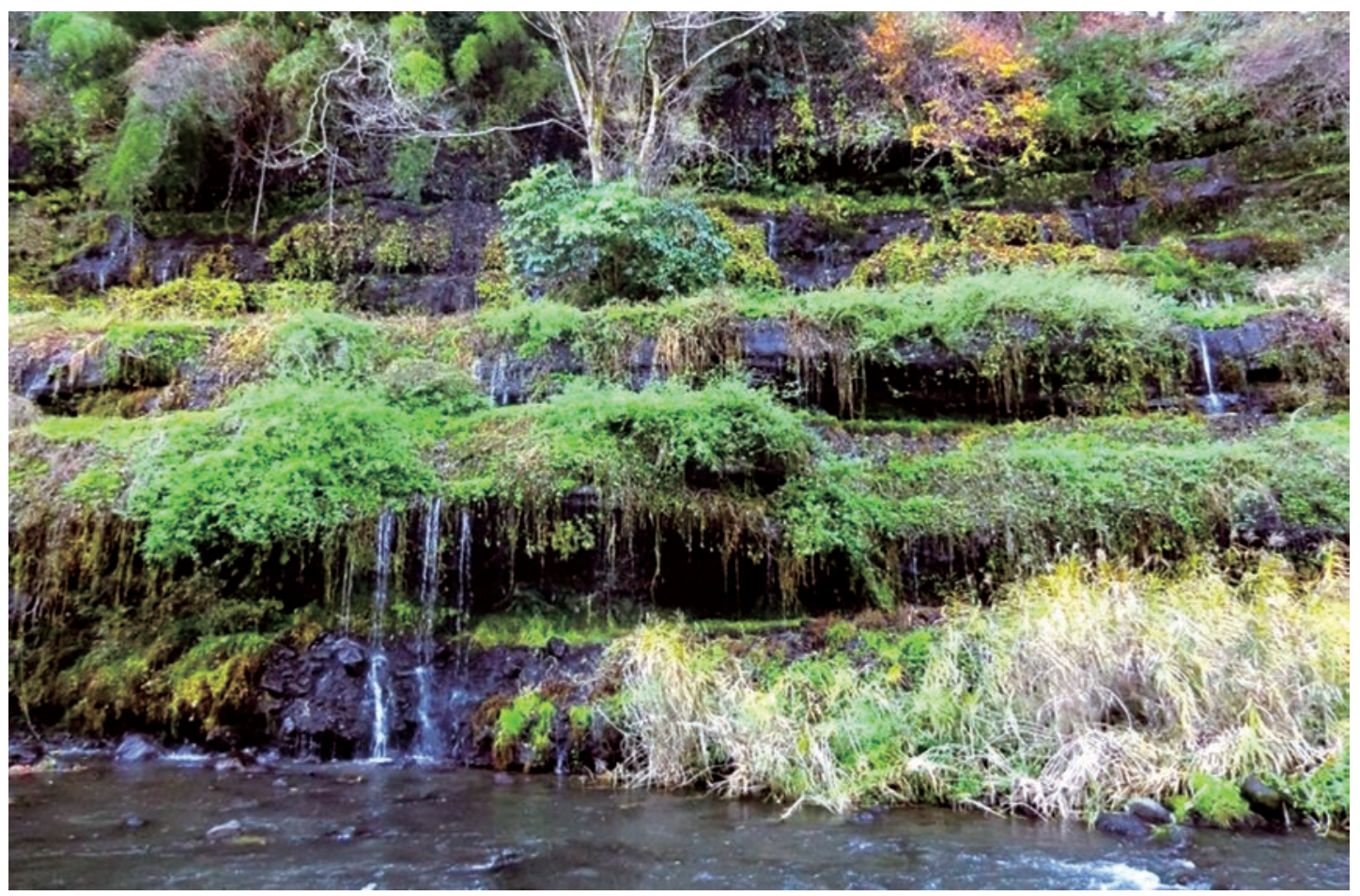

B 夏狩湧水群（太郎次郎の滝下流）

(写真提供：内山美恵子) 